(International Journal of Agriculture and Wildlife Science)
http://dergipark.org.tr/ijaws

Research Article

\title{
The Effects of Trunk Shape and Shoot Distance to Trunk on The Pomological Characteristics of Hayvard Kiwifruit
}

\author{
Pınar Öge Altun, Muharrem Özcan* \\ University of Ondokuz Mayıs, Department of Horticulture in Faculty of Agriculture, Samsun
}

Received: 23.05.2019 Accepted: 06.08.2019

\begin{abstract}
Keywords:
Kiwifruit vine, trunk shape, yield, quality

*Corresponding author

muozcan@omu.edu.tr

Abstract. In this study, different trunk shapes and distance of shoots to trunk in kiwifruit vine on fruit characteristics were determined. The effects of distance of shoots to the trunk on fruit quality parameters of kiwifruit vine have different trunk shape (upright and unshaped) were investigated in two different commercial kiwifruit orchards (well-cared and uncared). Three branches for each kiwifruit vine were selected in terms of distance of branches to trunk (near to trunk: $\sim 20 \mathrm{~cm}$ (NT), medium distance to trunk: $\sim 40 \mathrm{~cm}$ (MT) and far to trunk: $\sim 60 \mathrm{~cm}(\mathrm{FT}))$. It depends on the study years fruit number (10.00-48.80), fruit diameter $(5.07-6.12 \mathrm{~cm})$, fruit length $(6.41-7.70 \mathrm{~cm})$, fruit weight $(91.73-142.06 \mathrm{~g})$, fruit flesh firmness $(5.20-7.55 \mathrm{~kg})$, TSS amount in harvest maturity $(14.35-16.37 \%)$, TSS amount in ripening (6.80-12.00\%), TA in harvest maturity (1.24-1.85\%) and TA in ripening varied. As a result, trunk shape (upright and unshaped) was found to affect fruit quality parameters in order that upright trunk shape should be formed for fruit quality and convenience in cultural applications.
\end{abstract}

\section{Kivi Omcalarındaki Gövde Şekli ve Dalların Gövdeye Olan Uzaklığının Meyve Özellikleri Üzerine Etkileri}

\begin{abstract}
Anahtar kelimeler:
Kivi, gövde şekli, verim, kalite
\end{abstract}

\begin{abstract}
Özet. Kivide farklı gövde şekilleri ve dalların gövdeye olan uzaklıklarının, meyve özellikleri üzerine etkisini ortaya koymak amacıyla yürütülen bu çalışmada, 2 farklı (bakımlı ve bakımsız bahçe) üretici bahçesinde, 2 farklı gövde yapısına (düzgün-dik gövdeli, eğri-spiral gövdeli) sahip bitkilerde dalların gövdeye uzaklıklarının meyve özelliklerine etkileri incelenmiştir. Her bir bitkide gövdeye olan uzaklığa bağlı olarak (gövdeye yakın: $20 \mathrm{~cm}$ (NT), gövdeye orta uzak: $\sim 40 \mathrm{~cm}$ (MT) ve gövdeye uzak: $\sim 60 \mathrm{~cm}(\mathrm{FT})) 3$ dal seçilmiştir. Yıllara göre değişmekle birlikte elde edilen sonuçlara göre; meyve sayısı 10,00-48,80, meyve eni 5,07-6,12 cm, meyve boyu 6,41-7,70 cm, meyve ağırlığı 91,73-142,06 g, meyve eti sertliği 5,20-7,55 kg, hasat olumu SÇKM \%6,80-12,00, yeme olumu SÇKM \%14,35-16,37, hasat olumu TEA \%1,24-1,85, yeme olumu TEA \%0,40-0,70 değerleri arasında değişmiştir. Sonuç olarak, gövde şeklinin (düzgün veya eğri gövde olmasının) meyve özellikleri üzerinde etkili olduğu belirlenmiştir. Kalite ve kültürel uygulamaların kolaylığı için gövdelerin mutlaka düzgün gövde şeklinde oluşturulması önerilmektedir.
\end{abstract}




\section{INTRODUCTION}

Kiwifruit vine has been classified as perennial, transient and deciduous. Kiwifruit vines required a support system as the trunk is not capable of carrying the fruits and shoots. Therefore, a balance is established between plant vegetative and generative development with cultural applications (SamancI and Uslu 1998). The previous studies on quality and yield in kiwifruit are claimed that (1) pruning type and training system are two main cultural and technical applications, (2) training systems are varied depending on cultivars, planting distances, ecological conditions and growing techniques and (3) support system $160-250 \mathrm{~cm}$ height above soil is appropriate to shoots.

Plant shaped with training system should be formed as much as high and healthy to provide strong plant growth, strong and long shoot, crown width and fruit burden stated by Eriş (1989).

Samancl (1990) reported that supporting system at a certain height above ground in kiwifruit vines provides convenience during cultural practices, mechanization and harvest besides balanced tree growth. Additionally, forming to shoot system at above 1.4-1.8 $\mathrm{m}$ height or higher from ground level ensures better sun exposure insolation and kiwifruit vines may not affected by late spring frosts.

Cangi and Karadeniz (1999) stated that fruit yield and characteristics colud differed to orchards and elevation. They found that average fruit weight in kiwifruit was $75.21-113.10 \mathrm{~g}$; fruit width was 47.88-54.94 mm and fruit length was $58.53-68.32 \mathrm{~mm}$. Furthermore, total acidity was $1.47-2.00 \%$ at harvest period and it was $0.60-0.81 \%$ in ripening. TSS value varied from $7.55 \%$ to $11.3 \%$ at harvest period and $14.1 \%$ to $17.03 \%$ at ripening. Another study was carried out on qualitative and quantitative effects of shoot development and pruning over fruit quality and yield in kiwifruit by Aksu Uslu (2006). The researchers reported that average fruit weight was $42-115 \mathrm{~g}$, titratable acidity was $1.1-1.3 \%$ and TSS content was $8-13 \%$, when maximum and minimum values for each parameter considered for two years.

Kahraman (2012) indicated that $\mathrm{T}$ trellis system and pergola are usually used in kiwifruit for supporting system and a single upright trunk should be formed after planting until the seedling reaches to first wire or the trellis. It is emphasized that a stake should be used in order to protect seedlings from winds and mechanical damages. It is important that plant trunk should be maintained fully upright and trunks should be attached from the outside of the stake at certain points instead of wrapping trunk to stake in order to form upright and healthy vines.

Kiwifruit vine is not able to carry own canopy and different trunk shape in terms of height and shape emerge due to various application performed at sapling stage. Thus, determination of the effects of these trunk shapes are important.

Kiwifruit production introduced to Turkey in 1980s. The production has been rapidly increased and it reached to 61920 tons in 2018. Kiwifruit production is carried out in Marmara and West, East and Central Black sea regions of Turkey. Therefore, Marmara and Black sea are prominent regions in terms of important potential in kiwifruit production (Özcan, 2016; TUIK, 2018).

Tea and hazelnut are produced economically in Black sea region. On the other hand, kiwifruit vine growing in Black sea region have great importance due to appropriate ecological conditions for production, economic income in small areas, storage duration till six months, availability of different processing types and gradually acceptation of fruit consumption in region as well as in the country (Özcan, 2016).

The shape of trunk in kiwifruit vines gathered important benefits for protecting the canopy and in make the cultural practices well. In this study, it is aimed to determine effects of trunk shape and shoot distances to trunk on yield and fruit characteristics.

\section{MATERIAL AND METHOD}

The study carried out in two commercial kiwifruit orchards established with 'Hayward' cultivar in Çarşamba county of Samsun province (Turkey) during 2012 and 2013. Ten kiwifruit vines at each orchard (B1: uncared, B2: well-cared), were selected and five of them have upright trunk and other five have unshaped trunk (Figure 1). Totally 20 trees were used from both orchards. In each vine, three different shoot distances to trunk were investigated. These were; near to trunk (NT): $\sim 20 \mathrm{~cm}$, medium distance to trunk (MT): $\sim 40 \mathrm{~cm}$ and far to trunk (FT): $\sim 60 \mathrm{~cm}$.

The study conducted in 2012 and 2013 and climatic data of the application years were considered.

Thirty fruits were collected from each plant and analysis were performed in totally 600 fruits ( 2 orchards $\times 2$ trunk shape $\times 5$ tree $\times 3$ replication $\times 10$ fruits each replication $=600$ fruits). Fruits were harvested on 09 November in 2012 and 10 November in 2013. Fruit harvest was carried out at the stage of 7\% of TSS. 
Firstly, fruit diameter, fruit length, fruit number and fruit weight were measured, and then following analysis were performed at fruits after artificial ripening ripening by applying calcium carbide.

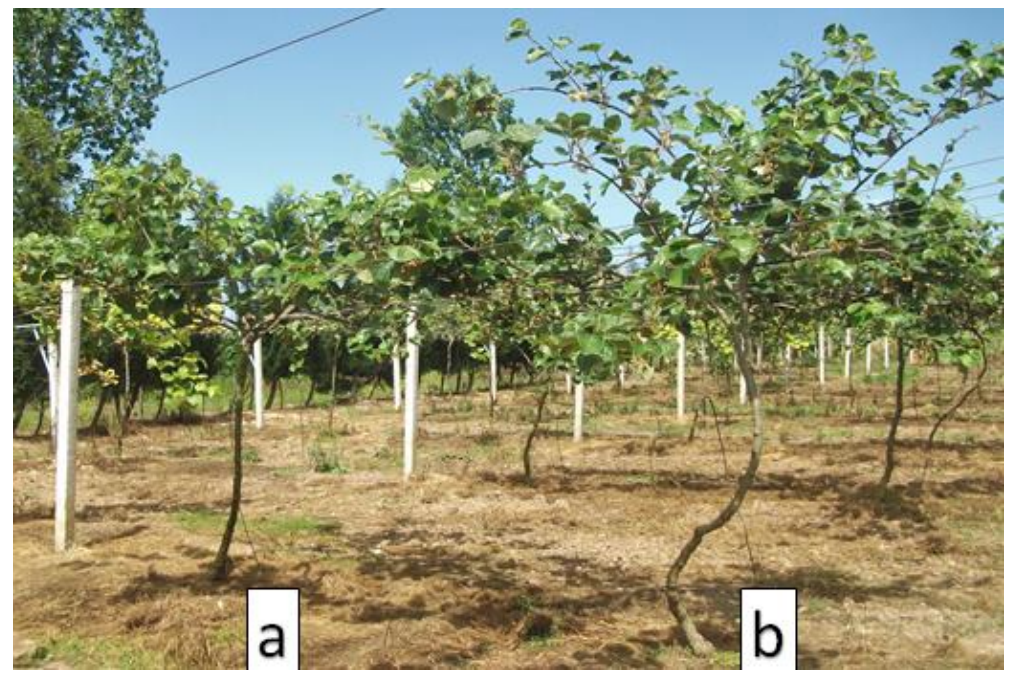

Figure 1. Trunk shape (a: Upright, b: Unshaped).

Şekil 1. Gövde yapısı (a: Düzgün şekilli, b: Eğri şekilli).

\section{Harvested Fruit Number / Total Bud Number (fruit number / bud)}

It was calculated as the ratio of the total number of harvested fruits on the shoots to total number of bud.

\section{Fruit Number (Piece)}

Fruits on shoots were counted.

\section{Fruit Diameter (cm)}

Diameter was measured with digital caliper at the middle part of the fruits.

\section{Fruit Length (cm)}

The length calculated as measuring the part of fruit stalk dip to flower dip.

\section{Fruit Weight $(\mathrm{cm})$}

It was determined as average weights of fruits on annual shoots.

\section{Fruit Yield (g/shoot)}

Fruit yield calculated as multiplying total fruit number on annual shoot and fruit weight.

\section{Fruit Flesh Firmness $\left(\mathrm{kg} \mathrm{cm}^{-2}\right)$}

Flesh firmness measured using hand penetrometer with $8 \mathrm{~mm}$ tip.

\section{Total Soluble Solid (TSS) content (\%)}

TSS measured with hand refractometer at both harvest and ripening period.

\section{Titratable Acidity (TA)}

A titration method was used to determine acidity of fruit juice in terms of citric acid (\%) (Kılıç et al., 1991) at both harvest and ripening period.

A factorial randomized block design was used for data analysis and mean comparisons were performed using Tukey HSD test. In data analysis, orchards were evaluated as blocks and each year was tested in itself. Data belongs to statistically different groups were codded with different letter as shown in tables.

\section{RESULTS AND DISCUSSION}

\section{Climatic Data}

Monthly average temperature and relative humidity during the study (in 2012-2013) given in Table 1 (Turkish State Meteorological Service, 2015). According to years (except the months of December, January, 
February and March), relative humidity and temperatures were in parallel and climatic data during the study were also in parallel with long terms data in study area (Turkish State Meteorological Service, 2015). This data demonstrate that extremes climatic conditions were not seen during study.

Table 1. Temperature and relative humidity values of study years in Samsun province.

Çizelge 1. Samsun ili deneme yllarına ait sıcaklık ve oransal nem değerleri.

\begin{tabular}{|c|c|c|c|c|c|c|c|c|c|c|c|c|c|}
\hline \multirow{2}{*}{$\begin{array}{l}\text { Meteorological } \\
\text { elements }\end{array}$} & \multirow{2}{*}{ Years } & \multicolumn{12}{|c|}{ Months } \\
\hline & & 1 & 2 & 3 & 4 & 5 & 6 & 7 & 8 & 9 & 10 & 11 & 12 \\
\hline \multirow{2}{*}{ Temperature } & 2012 & 1.4 & 0.3 & 4.8 & 13.8 & 17.1 & 23.2 & 26.0 & 25.0 & 21.6 & 16.6 & 10.8 & 5.2 \\
\hline & 2013 & 3.6 & 5.9 & 8.6 & 13.2 & 18.7 & 22.1 & 24.5 & 24.8 & 19.8 & 13.0 & 10.1 & 1.5 \\
\hline \multirow{2}{*}{$\begin{array}{l}\text { Relative } \\
\text { humidity }\end{array}$} & 2012 & 76.9 & 73.0 & 65.4 & 58.4 & 64.7 & 50.4 & 47.0 & 45.7 & 49.1 & 63.2 & 73.6 & 78.2 \\
\hline & 2013 & 75.4 & 73.9 & 63.2 & 61.8 & 56.9 & 50.6 & 46.3 & 45.9 & 49.3 & 55.7 & 68.1 & 68.2 \\
\hline
\end{tabular}

\section{Fruit Number}

The effects of trunk shape on fruit number were insignificant in 2012 and it was significant in 2013. Fruit numbers were determined 30.37 in upright trunked kiwifruit vines and 30.87 in unshaped trunks in 2012 and it was 19.67 in upright trunks and 13.40 in unshaped trunks in 2013. These results show that the fruit numbers decreased as the distance between trank and shoots increased. It is observed that the orchard features have significant effects on this change which varies by years. The difference between orchards was found statistically significant in both trial years, while interaction of trunk shape and shoot distance was insignificant (Table 2). Though the effects of distance between branch and trunk were found insignificant, higher fruit numbers on shoots close to trunk were observed in unshaped trunks. On the other hand, higher fruit numbers were observed on branches at medium and far distance to trunk in upright trunks. The maintenance conditions were seen reason of differences among orchards, and higher fruit number were found in B1 orchard which has better maintenance condition.

The highest number of fruits (33.20) was found on shoots near to trunk in unshaped trunks in 2012, and it (24.40) was found on shoots near to trunk in upright trunks in 2013. The lowest number of fruits was observed on shoots far from trunk in both trunk shapes (Table 2). The reason of the decrease in fruit number may be arisen from increasing of shoot length, increase in distance between shoot and main branch in plant species with higher annual shoot length such as kiwifruit. Karaçalı (2006) reported that only developing shoots are competing with fruits in the intake of water and mineral substances. Thus, cultural applications such as girdling and tipping should be performed to support fruit set and development. Basım and Uzun (2003) stated that 493 fruits per vine in Hayward cultivar and 2259 fruits per vine in Bruno cultivar could be taken. Şeker et al., (2003a) indicated total fruit number in 'Hayward' cultivar was 571 and Şeker et al., (2003b) determined the highest fruit number depending on different pruning applications in 'Hayward' cultivar was 313.2 per vine. Although our study is based on shoots, total fruit number agreed with results of previous studies considering whole plant.

Table 2. The effect of trunk shape and shoot distance on fruit number.

Çizelge 2. Gövde yapısı ve dal uzaklı̆ının meyve sayısına etkisi (adet).

\begin{tabular}{clccccc}
\hline Years & $\begin{array}{c}\text { Distance to } \\
\text { trunk }\end{array}$ & \multicolumn{2}{c}{ Trunk Shape } & \multicolumn{2}{c}{ Orchard } & Average \\
& Upright & Unshaped & B1 & B2 & \\
\hline \multirow{2}{*}{2012} & Near (NT) & 28.90 & 33.20 & 43.50 & 18.60 & 31.05 \\
& Medium & 31.00 & 32.90 & 40.80 & 23.10 & 31.95 \\
& (MT) & 31.20 & 26.50 & 37.40 & 20.30 & 28.85 \\
& Far (FT) & $\mathbf{3 0 . 3 7}$ & $\mathbf{3 0 . 8 7}$ & $\mathbf{4 0 . 5 7} \mathbf{a}^{* *}$ & $\mathbf{2 0 . 6 7} \mathbf{~ b}$ & 30.62 \\
& Average & & ${ }^{* *} \mathrm{p}<0.01$ & & & \\
\hline \multirow{2}{*}{2013} & Near (NT) & 24.40 & 13.90 & 21.40 & 16.90 & 19.15 \\
& Medium & 20.40 & 13.50 & 20.70 & 13.20 & 16.95 \\
& (MT) & 14.20 & 12.80 & 14.40 & 12.60 & 13.50 \\
& Far (FT) & $\mathbf{1 9 . 6 7} \mathbf{a}^{*}$ & $\mathbf{1 3 . 4 0} \mathbf{b}$ & $\mathbf{1 8 . 8 3} \mathbf{a}^{*}$ & $\mathbf{1 4 . 2 3} \mathbf{~ b}$ & 16.53 \\
& Average & & ${ }^{*} \mathrm{p}<0.05$ & & & \\
\hline
\end{tabular}




\section{Number of Harvested Fruit/Total Bud Number}

The effects of trunk shapes, orchards and distances of branch to trunk were statistically in significant in both of the study years. The ratios of fruit/bud in upright trunks were 3.97 and 3.0 for study years respectively. The ratios of fruit/bud varied between 3.53-4.73 in 2012 and 2.32-4.32 in 2013. The ratios of fruit/bud considering trunk shapes were similar and the values varied between 3.72-4.35 (in 2012) and 2.56-3.47 (in 2013). The interaction of trunk shape and branch distance was found statistically insignificant (Table 3).

The ratio of fruit/bud in 2012 was higher than its in 2013 that may be occurred due to the higher temperature and lower humidity during flowering and fruit set period (in May) in 2013 (Table 1). When we compared the values in terms of orchards, it has been seen that the number of bud breaking and fruit setting ratio were nearly similar in both orchards.

Table 3. The effect of trunk shape and shoot distance on fruit/bud ratios.

Çizelge 3. Gövde yapısı ve dal uzaklığının meyve/göz oranına etkisi.

\begin{tabular}{clccccc}
\hline Years & $\begin{array}{c}\text { Branch } \\
\text { Distance }\end{array}$ & \multicolumn{2}{c}{ Trunk Shape } & \multicolumn{2}{c}{ Orchards } & Average \\
& Near (NT) & 4.00 & 3.72 & 4.03 & 3.69 & 3.86 \\
\multirow{2}{*}{2012} & Medium & 4.08 & 3.83 & 4.09 & 3.82 & 3.96 \\
& (MT) & 4.21 & 4.35 & 4.60 & 3.96 & 4.28 \\
& Far (FT) & $\mathbf{4 n s h a p e d}$ & B1 & B2 & \\
& Average & $\mathbf{4 . 1 0}$ & $\mathbf{3 . 9 7}$ & $\mathbf{4 . 2 4}$ & $\mathbf{3 . 8 2}$ & 4.03 \\
& & & & & & \\
\hline \multirow{2}{*}{2013} & Near (NT) & 3.47 & 2.56 & 3.05 & 2.97 & 3.01 \\
& Medium & 3.53 & 3.06 & 3.45 & 3.14 & 3.30 \\
& (MT) & 3.68 & 3.37 & 4.13 & 2.91 & 3.52 \\
& Far (FT) & $\mathbf{3 . 5 6}$ & $\mathbf{3 . 0 0}$ & $\mathbf{3 . 5 5}$ & $\mathbf{3 . 0 1}$ & 3.28 \\
& Average & $\mathbf{3}$ & Insignificant & & & \\
\hline
\end{tabular}

\section{Fruit Diameter}

The effects of trunk shapes on fruit dimeter were in significant in 2012 and significant in 2013. Fruit diameter was found $5.28 \mathrm{~cm}$ in upright trunks and it was 5.25 in unshaped trunks in 2012 . Following year it was $5.55 \mathrm{~cm}$ in upright trunk and 5.82 in unshaped trunk (Table 4). The differences among orchards were statistically significant in both study years. Fruit diameter in kiwifruit has been reported to vary by Samancı $(1990)(6.8 \mathrm{~cm})$; Eriş (1989) (3-4.5 cm); Aksu Uslu (2006) (3.5-14.4 cm); Basım and Uzun (2003) (4.8 cm). Bostan and Günay (2013) determined that average fruit diameters vary from $4.565 \mathrm{~cm}$ to $6.451 \mathrm{~cm}$. Kadiroglu Karaoğlan (2011), stating that fruit diameter reached to $5.161 \mathrm{~cm}$ in $20^{\text {th }}$ week measurement in their study conducted to determine morphological changes during the period from fruit setting to harvest in 'Hayward' cultivar. Sarıçiçek (2010), reported that fruit diameter was between $4.996 \mathrm{~cm}$ and $5.214 \mathrm{~cm}$ in their study on determination effects of boron fertilization on yield and mineral nutrients of leaves. In addition, Yılmaz (2016) indicated that fruit diameter varied from $2.741 \mathrm{~mm}$ to $5.319 \mathrm{~cm}$. Our results generally agreed with results reported in previous studies.

Table 4. The effects of trunk shape and shoot distance on fruit diameter (cm).

Çizelge 4. Gövde yapısı ve dal uzaklığının meyve enine etkisi $(\mathrm{cm})$.

\begin{tabular}{|c|c|c|c|c|c|c|}
\hline \multirow[t]{2}{*}{ Years } & \multirow{2}{*}{$\begin{array}{l}\text { Branch } \\
\text { Distance }\end{array}$} & \multicolumn{2}{|c|}{ Trunk Shape } & \multicolumn{2}{|c|}{ Orchards } & \multirow[t]{2}{*}{ Average } \\
\hline & & Upright & Unshaped & B1 & B2 & \\
\hline \multirow{5}{*}{2012} & Near (NT) & 5.24 & 5.32 & 5.12 & 5.43 & 5.28 \\
\hline & $\begin{array}{l}\text { Medium } \\
\text { (MT) }\end{array}$ & 5.36 & 5.23 & 5.24 & 5.35 & 5.30 \\
\hline & Far (FT) & 5.26 & 5.20 & 5.12 & 5.33 & 5.23 \\
\hline & Average & 5.28 & 5.25 & $5.16 \mathrm{~b}$ & $5.37 a^{* *}$ & 5.27 \\
\hline & & & ${ }^{* *} p<0.01$ & & & \\
\hline \multirow{4}{*}{2013} & Near (NT) & 5.50 & 5.79 & 5.51 & 5.77 & 5.64 \\
\hline & $\begin{array}{l}\text { Medium } \\
\text { (MT) }\end{array}$ & 5.59 & 5.73 & 5.48 & 5.84 & 5.66 \\
\hline & Far (FT) & 5.57 & 5.93 & 5.58 & 5.93 & 5.75 \\
\hline & Average & $5.55 \mathrm{~b}$ & $\begin{array}{c}5.82 a^{* *} \\
{ }^{*} p<0.01\end{array}$ & $5.52 \mathrm{~b}$ & $5.84 \mathrm{a}^{* *}$ & 5.68 \\
\hline
\end{tabular}




\section{Fruit Length}

The effect of trunk shape on fruit length was found statistically insignificant in 2012 and it was significant in 2013. Differences among orchards were significant for 2013. The fruit lengths were measured as $6.81 \mathrm{~cm}$ in upright trunks and $6.69 \mathrm{~cm}$ in unshaped trunks in 2012. In 2013, fruit lengths were $6.83 \mathrm{~cm}$ in upright trunks and $7.08 \mathrm{~cm}$ in unshaped trunks (Table 5). Our results generally are in consistent with previous studies reported by Basım and Uzun (2003) $(6.1 \mathrm{~cm})$; Şeker et al., (2003a) $(6.0 \mathrm{~cm})$; Bostan and Günay (2014) $(57.15-83.69 \mathrm{~mm})$; Sarıçiçek (2010) (5.974-5.504 cm); Yılmaz (2016) (3.4913-6.3681).

Table 5. The effect of trunk shape and shoot distance on fruit length (cm).

Çizelge 5. Gövde yapısı ve dal uzaklığının meyve boyuna etkisi (cm).

\begin{tabular}{|c|c|c|c|c|c|c|}
\hline \multirow[t]{2}{*}{ Years } & \multirow{2}{*}{$\begin{array}{c}\text { Branch } \\
\text { Distance }\end{array}$} & \multicolumn{2}{|c|}{ Trunk Shape } & \multicolumn{2}{|c|}{ Orchards } & \multirow[t]{2}{*}{ Average } \\
\hline & & Upright & Unshaped & B1 & B2 & \\
\hline \multirow{4}{*}{2012} & Near (NT) & 6.76 & 6.75 & 6.63 & 6.88 & 6.75 \\
\hline & $\begin{array}{l}\text { Medium } \\
\text { (MT) }\end{array}$ & 6.87 & 6.66 & 6.79 & 6.74 & 6.77 \\
\hline & Far (FT) & 6.81 & 6.66 & 6.59 & 6.88 & 6.73 \\
\hline & Average & 6.81 & 6.69 & 6.67 & 6.83 & 6.75 \\
\hline \multirow{5}{*}{2013} & Near (NT) & 6.66 & 6.97 & 6.47 & 7.16 & 6.82 \\
\hline & $\begin{array}{l}\text { Medium } \\
(\mathrm{MT})\end{array}$ & 6.84 & 7.01 & 6.58 & 7.27 & 6.92 \\
\hline & Far (FT) & 6.98 & 7.27 & 6.69 & 7.56 & 7.13 \\
\hline & Average & $6.83 \mathrm{~b}$ & $7.08 a^{*}$ & $6.58 \mathrm{~b}$ & $7.33 a^{* *}$ & 6.96 \\
\hline & \multicolumn{6}{|c|}{${ }^{*} p<0.05{ }^{* *} p<0.01$} \\
\hline
\end{tabular}

\section{Fruit Weight}

The results of fruit weight were found statistically similar with fruit length. It was statistically in significant in 2012, while it was significant in 2013. Fruit weights were $110.81 \mathrm{~g}$ in upright trunks and $108.52 \mathrm{~g}$ in unshaped trunks in 2012. In 2013, fruit weights were $107.98 \mathrm{~g}$ in upright trunks and $124.45 \mathrm{~g}$ in unshaped trunks. It is obviously seen that fruit weight in upright trunks was higher in 2012, while it was found higher in unshaped trunks in 2013 (Table 6). Average fruit weight of Hayward cultivar was reported as 75.21-113.10 g by Cangi and Karadeniz (1999) and 65.357-89.561 g by Esen (2009). Tarakçığlu et al., (2006), stating that the fruit weight was varied among years in their study. In the first year of their study fruit weight was estimated as $114.7-136.0 \mathrm{~g}$ and it was 69.4-83.2 $\mathrm{g}$ at the second year. Günay (2009) reported that fruit weight was 88.16-104.35 g. Sarıçiçek (2010), stating that fruit weight was varied among years and it was found to change from $87.93 \mathrm{~g}$ and $105.92 \mathrm{~g}$. Additionally, Yılmaz (2016) found that the fruit weights were between 13.288 and $92.987 \mathrm{~g}$. These results were generally in parallel with our results. In our study, higher fruit weight in unshaped trunks in 2013 may be arisen from lower fruit number in unshaped trunks at the same period. The fruit weight has been known to be affected from nutrition conditions and ecological conditions. Therefore, the differences among study orchards in 2013 may be occurred due to these factors.

Table 6. The effect of trunk shape and shoot distance on fruit weight (g).

Çizelge 6. Gövde yapısı ve dal uzaklığının meyve ağırlığına etkisi (g).

\begin{tabular}{|c|c|c|c|c|c|c|}
\hline \multirow[t]{2}{*}{ Years } & \multirow{2}{*}{$\begin{array}{c}\text { Branch } \\
\text { Distance }\end{array}$} & \multicolumn{2}{|c|}{ Trunk Shape } & \multicolumn{2}{|c|}{ Orchards } & \multirow[t]{2}{*}{ Average } \\
\hline & & Upright & Unshaped & B1 & B2 & \\
\hline \multirow{4}{*}{2012} & Near (NT) & 107.90 & 111.20 & 102.02 & 117.07 & 109.55 \\
\hline & $\begin{array}{l}\text { Medium } \\
(\mathrm{MT})\end{array}$ & 114.64 & 107.85 & 109.08 & 113.41 & 111.25 \\
\hline & Far (FT) & 109.88 & 106.50 & 101.21 & 115.17 & 108.19 \\
\hline & Average & 110.81 & 108.52 & 104.10 & 115.22 & 109.66 \\
\hline \multirow{4}{*}{2013} & Near (NT) & 103.62 & 122.20 & 106.33 & 119.49 & 112.91 \\
\hline & $\begin{array}{l}\text { Medium } \\
(\mathrm{MT})\end{array}$ & 109.48 & 119.62 & 103.61 & 125.50 & 114.55 \\
\hline & Far (FT) & 110.85 & 131.52 & 110.00 & 132.37 & 121.19 \\
\hline & Average & 107.98 b & $\begin{array}{l}124.45 a^{* *} \\
{ }^{* *} p<0.01\end{array}$ & $106.65 a^{* *}$ & $125.78 \mathrm{~b}$ & 116.22 \\
\hline
\end{tabular}




\section{Fruit Yield}

The effects of trunk shapes on fruit yield of selected branches were in significant both in 2012 and 2013. Fruit yield was $3331.13 \mathrm{~g}$ in upright trunks and it was $3246.17 \mathrm{~g}$ in unshaped trunks in 2012. Fruit yield was $2073.34 \mathrm{~g}$ in upright trunks and it was $1642.33 \mathrm{~g}$ in 2013. The highest fruit yield both in 2012 and 2013 was obtained in upright trunks considering yield based on trunk shapes (Table 7). Basım and Uzun (2003) reported that minimum yield per plant was $15.0 \mathrm{~kg}$, while it was maximum with $63 \mathrm{~kg} \mathrm{plant}^{-1}$. Additionally, Şeker et al., (2003a) stating that yield was $44.5 \mathrm{~kg} \mathrm{plant}^{-1}$ and it was $1800 \mathrm{~kg} \mathrm{da}^{-1}$. Tarakçıoğlu et al., (2006) estimated that fruit yield was varied between 21.9 and $32.4 \mathrm{~kg} \mathrm{plant}^{-1}$ in the first year of their study and it was between 99.9 and $139.9 \mathrm{~kg} \mathrm{plant}^{-1}$ in the second year. In our study, although yield was estimated based on shoot, it can be said that the results are in consistent with the results of previous studies when the current results are adapted to yield per plant.

Table 7. The effect of trunk shape and shoot distance on yield (g).

Çizelge 7. Gövde yapısı ve dal uzakliğının verime etkisi (g).

\begin{tabular}{|c|c|c|c|c|c|c|}
\hline \multirow[t]{2}{*}{ Years } & \multirow{2}{*}{$\begin{array}{l}\text { Branch } \\
\text { Distance }\end{array}$} & \multicolumn{2}{|c|}{ Trunk Shape } & \multicolumn{2}{|c|}{ Orchards } & \multirow[t]{2}{*}{ Average } \\
\hline & & Upright & Unshaped & B1 & B2 & \\
\hline \multirow{5}{*}{2012} & Near (NT) & 3085.13 & 3456.40 & 4384.40 & 2157.13 & 3270.76 \\
\hline & $\begin{array}{l}\text { Medium } \\
\text { (MT) }\end{array}$ & 3568.04 & 3488.92 & 4408.16 & 2648.81 & 3528.48 \\
\hline & Far (FT) & 3340.20 & 2793.20 & 3827.57 & 2305.83 & 3066.70 \\
\hline & Average & 3331.13 & 3246.17 & $4206.71 a^{\star *}$ & $2370.59 \mathrm{~b}$ & 3288.65 \\
\hline & \multicolumn{6}{|c|}{${ }^{* *} p<0,01$} \\
\hline \multirow{5}{*}{2013} & Near (NT) & 2301.15 & 1313.10 & 1613.35 & 2000.91 & 1807.13 \\
\hline & $\begin{array}{l}\text { Medium } \\
\text { (MT) }\end{array}$ & 1873.16 & 1480.70 & 1753.13 & 1600.72 & 1676.93 \\
\hline & Far (FT) & 2045.71 & 2133.19 & 2568.02 & 1610.88 & 2089.45 \\
\hline & Average & 2073.34 & 1642.33 & 1978.17 & 1737.50 & 1857.83 \\
\hline & \multicolumn{6}{|c|}{ Insignificant } \\
\hline
\end{tabular}

\section{Fruit Flesh Firmness}

The effects of trunk shape were statistically insignificant in both years. Fruit flesh firmness' were measured $7.06 \mathrm{~kg}$ in upright trunks and $6.81 \mathrm{~kg}$ in unshaped trunks in 2012, while fruit flesh firmness' were $6.44 \mathrm{~kg}$ in upright trunks and $6.08 \mathrm{~kg}$ in unshaped trunks in 2013 (Table 8). It is seen that the values of flesh firmness in upright trunks were higher than in unshaped trunks in both of the study years and our results agreed with those of previous studies. A study conducted by Esen and Özcan (2016) in order to determine fruit development and appropriate harvest period in kiwifruit growing in Ünye (Ordu, Turkey) province stating that the fruit flesh firmness was varied between 8.88 and $9.03 \mathrm{~kg}$. Basım and Uzun (2003) reported that fruit flesh firmness in 'Hayvard' cultivar was $7.8 \mathrm{~kg}$, while it was $6.7 \mathrm{~kg}$ in 'Bruno' cultivar. In addition, Zenginbal et al., (2005) reported that fruit flesh firmness was $7.5-9 \mathrm{~kg}$ in 'Hayward' cultivar and it was7.5-8 kg in 'Bruno' cultivar during harvest period in kiwifruit grown in ecological conditions of Rize province in Turkey. Duman (2011) suggested that flesh firmness in kiwifruit should be $6-9 \mathrm{~kg}$ during harvest period and it should be $0.5-0.8 \mathrm{~kg}$ in maturity period. Bostan and Günay (2014) determined that fruit flesh firmness varied between $0.47 \mathrm{~kg}$ and $0.64 \mathrm{~kg}$. Yılmaz (2016) reported that flesh firmness was varied from $7.632 \mathrm{~kg}$ to $11.330 \mathrm{~kg}$ during harvest period.

Table 8. The effects of trunk shape and shoot distance on fruit flesh firmness $(\mathrm{kg})$. Çizelge 8. Gövde yapısı ve dal uzaklığının meyve eti sertlik değerine etkisi (kg).

\begin{tabular}{lllllll}
\hline Years & Branch & \multicolumn{2}{l}{ Trunk Shape } & \multicolumn{2}{c}{ Orchards } & Average \\
& Distance & Upright & Unshaped & B1 & B2 & \\
\hline \multirow{3}{*}{2012} & Near (NT) & 6.95 & 6.88 & 7.11 & 6.73 & 6.92 \\
& Medium (MT) & 7.45 & 7.02 & 7.36 & 7.12 & 7.24 \\
& Far (FT) & 6.76 & 6.54 & 6.47 & 6.83 & 6.65 \\
& Average & $\mathbf{7 . 0 6}$ & $\mathbf{6 . 8 1}$ & $\mathbf{6 . 9 8}$ & $\mathbf{6 . 8 9}$ & 6.93 \\
& & & & & \\
2013 & Near (NT) & 6.75 & 6.65 & 6.78 & 6.63 & 6.70 \\
& Medium (MT) & 6.40 & 5.60 & 5.70 & 6.30 & 6.00 \\
& Far (FT) & 6.18 & 6.00 & 6.20 & 5.98 & 6.09 \\
& Average & $\mathbf{6 . 4 4}$ & $\mathbf{6 . 0 8}$ & $\mathbf{6 . 2 3}$ & $\mathbf{6 . 3 0}$ & 6.26 \\
& & & Insignificant & & & \\
\hline
\end{tabular}




\section{The Total Soluble Solids (TSS) in Harvest Maturity}

The effects of trunk shapes to TSS were statistically insignificant in both study years. TSS values were $7.33 \%$ in upright trunks and $7.44 \%$ in unshaped trunks in 2012 , while it was $11.29 \%$ in upright trunks and $11.64 \%$ in unshaped trunks in 2013 (Table 9). Aksu Uslu (2006) determined that average TSS were 8\% in the first year and $13 \%$ in the second year of the study carried out to evaluate effects of pruning and shoot development on fruit quality and yield. Zenginbal et al., (2005) reported that TSS amount was between $9.5 \%$ and $10 \%$ during harvest maturity stage in kiwifruit grown in ecological conditions of Rize province of Turkey. In addition, a study conducted for the determination effects of altitude and direction of orchards on fruit quality parameters of 'Hayward' cultivar in ecological conditions of Ordu province of Turkey by Günay (2009) stating that TSS amount based on two years average data was $12.70-13.83 \%$. Cangi and Atalay (2006) investigated different bud setting level in 'Hayward' cultivar and they determined that TSS amount changes according to number of bud per wine. The researcher also found that TSS amount was the lowest during the highest bud setting level (300 buds/wine) and there was a negative correlation between average fruit weight, yield and TSS amount. YIlmaz 2016 stated that TSS was between $2.944 \%$ and $13.306 \%$ in harvest maturity. These notifications of previous results are in consistent with our results.

Table 9. The effects of trunk shape and shoot distance on TSS amount in harvest maturity (\%).

Çizelge 9. Gövde yapısı ve dal uzaklığının hasat olumu SÇKM değerine etkisi (\%).

\begin{tabular}{|c|c|c|c|c|c|c|}
\hline \multirow[t]{2}{*}{ Years } & \multirow{2}{*}{$\begin{array}{c}\text { Branch } \\
\text { Distance }\end{array}$} & \multicolumn{2}{|c|}{ Trunk Shape } & \multicolumn{2}{|c|}{ Orchards } & \multirow[t]{2}{*}{ Average } \\
\hline & & Upright & Unshaped & B1 & B2 & \\
\hline \multirow{4}{*}{2012} & Near (NT) & 7.26 & 7.42 & 7.14 & 7.53 & 7.34 \\
\hline & Medium (MT) & 7.33 & 7.12 & 6.82 & 7.63 & 7.23 \\
\hline & Far (FT) & 7.40 & 7.80 & 7.80 & 7.40 & 7.60 \\
\hline & Average & 7.33 & 7.44 & 7.25 & 7.52 & 7.39 \\
\hline \multirow{5}{*}{2013} & Near (NT) & 11.10 & 11.70 & 11.13 & 11.67 & 11.40 \\
\hline & Medium (MT) & 11.32 & 11.68 & 11.23 & 11.77 & 11.50 \\
\hline & Far (FT) & 11.46 & 11.54 & 11.16 & 11.83 & 11.50 \\
\hline & Average & 11.29 & 11.64 & $11.18 \mathrm{~b}$ & $11.76 a^{*}$ & 11.47 \\
\hline & & & ${ }^{*} p<0.05$ & & & \\
\hline
\end{tabular}

\section{TSS Amount in Ripening}

The effects of trunk shape were statistically insignificant in both study years. TSS amounts were found $15.11 \%$ in upright trunks and $15.03 \%$ in unshaped trunks in 2012, while it was found $15.45 \%$ in upright trunks and $15.31 \%$ in unshaped trunks in 2013 (Table 10). A study on determination of optimum plant development and harvest time in kiwifruit growing in Ünye province conducted by Esen and Özcan (2016) stating that TSS amounts in ripening were $9.76 \%, 10.33 \%$ and $10.04 \%$ in seaside, medium and high altitude zones respectively. Zenginbal et al., (2005) reported that TSS amount in ripening was between $13 \%$ and $14 \%$ in their study on phenological observations and pomological analysis in kiwifruit growing in Rize province in Turkey. Kubal (2016) stated that TSS amounts in ripening were between $10.433 \%$ and $12.150 \%$. TSS values in our study agreed with those of previous studies.

Table 10. The effects of trunk shape and shoot distance on TSS amount in ripening (\%). Çizelge 10. Gövde yapısı ve dal uzaklığının yeme olumu SÇKM değerine etkisi (\%).

\begin{tabular}{|c|c|c|c|c|c|c|}
\hline \multirow[t]{2}{*}{ Years } & \multirow{2}{*}{$\begin{array}{l}\text { Branch } \\
\text { Distance }\end{array}$} & \multicolumn{2}{|c|}{ Trunk Shape } & \multicolumn{2}{|c|}{ Orchards } & \multirow[t]{2}{*}{ Average } \\
\hline & & Upright & Unshaped & B1 & B2 & \\
\hline \multirow{4}{*}{2012} & Near (NT) & 14.98 & 15.20 & 14.87 & 15.32 & 15.09 \\
\hline & $\begin{array}{l}\text { Medium } \\
\text { (MT) }\end{array}$ & 14.87 & 14.90 & 14.52 & 15.25 & 14.88 \\
\hline & Far (FT) & 15.48 & 14.99 & 14.69 & 15.78 & 15.23 \\
\hline & Average & 15.11 & 15.03 & 14.69 & 15.45 & 15.07 \\
\hline \multirow{5}{*}{2013} & Near (NT) & 15.59 & 15.78 & 15.15 & 16.22 & 15.68 \\
\hline & $\begin{array}{l}\text { Medium } \\
\text { (MT) }\end{array}$ & 15.43 & 14.94 & 14.47 & 15.90 & 15.18 \\
\hline & Far (FT) & 15.33 & 15.22 & 15.00 & 15.55 & 15.27 \\
\hline & Average & 15.45 & 15.31 & $14.87 \mathrm{~b}$ & $15.89 a^{* *}$ & 15.38 \\
\hline & & & ${ }^{* *} p<0.01$ & & & \\
\hline
\end{tabular}




\section{Titratable Acidity in Harvest Maturity (TA)}

The effects of trunk shapes were found statistically insignificant in both study years. TA values were $1.35 \%$ in both of the trunk shapes in 2012, while the TA values were $1.70 \%$ and $1.67 \%$ in upright and unshaped trunks in 2013 respectively (Table 11). A study on determination of optimum plant development and harvest time in kiwifruit growing in Ünye province conducted by Esen and Özcan (2016) reported that the TA values were 2.5\% in seaside zone, $2.56 \%$ in medium altitude zone and $2.06 \%$ in high altitude zone. In addition, TA values in harvest maturity were found $1.10-1.26 \%$ and $1.1-1.3 \%$ by Aksu Uslu (2006) and Günay (2009) respectively. Yilmaz (2016) indicated that TA values were $0.484-1.496 \%$. Our results are agreed with the results of previous studies.

Table 11. The effects of trunk shape and shoot distance on TA in harvest maturity (\%).

Çizelge 11. Gövde yapısı ve dal uzaklı̆ının hasat olumu TEA değerine etkisi (\%).

\begin{tabular}{|c|c|c|c|c|c|c|}
\hline \multirow[t]{2}{*}{ Years } & \multirow{2}{*}{$\begin{array}{l}\text { Branch } \\
\text { Distance }\end{array}$} & \multicolumn{2}{|c|}{ Trunk Shape } & \multicolumn{2}{|c|}{ Orchards } & \multirow[t]{2}{*}{ Average } \\
\hline & & Upright & Unshaped & B1 & B2 & \\
\hline \multirow[b]{2}{*}{2012} & Near (NT) & 1.30 & 1.33 & 1.24 & 1.39 & 1.32 \\
\hline & $\begin{array}{l}\text { Medium } \\
(\mathrm{MT})\end{array}$ & 1.46 & 1.33 & 1.38 & 1.41 & 1.40 \\
\hline \multirow{7}{*}{2013} & Far (FT) & 1.28 & 1.39 & 1.30 & 1.37 & 1.33 \\
\hline & Average & 1.35 & 1.35 & 1.31 & 1.39 & 1.35 \\
\hline & Near (NT) & 1.72 & 1.75 & 1.70 & 1.77 & 1.74 \\
\hline & $\begin{array}{l}\text { Medium } \\
\text { (MT) }\end{array}$ & 1.70 & 1.67 & 1.65 & 1.73 & 1.69 \\
\hline & Far (FT) & 1.69 & 1.58 & 1.63 & 1.64 & 1.64 \\
\hline & Average & 1.70 & 1.67 & 1.66 & 1.71 & 1.69 \\
\hline & \multicolumn{6}{|c|}{ Insignificant } \\
\hline
\end{tabular}

\section{Titratable Acidity in Ripening (TA)}

The effects of trunk shapes were found statistically insignificant in both study years. TA values were $0.50 \%$ in upright trunks and $0.44 \%$ in unshaped trunks in 2012 , while the values were $0.60 \%$ in upright trunks and $0.64 \%$ in unshaped trunks in 2013 (Table 12). Esen and Özcan (2016) reported that TA values in ripening were 1.47\% in seaside zone, \%1.39 in medium altitude zone and $1.12 \%$ in high altitude zone. In addition, Kubal (2016) similarly stated that the TA values in ripening were varied between $1.170 \%$ and $1.387 \%$. In our study, results of titratable acidity are in consistent with those of previous studies.

Table 12. The effects of trunk shapes and shoot distance on TA in ripening (\%). Çizelge 12. Gövde yapısı ve dal uzaklı̆ının yeme olumu TEA değerine etkisi (\%).

\begin{tabular}{llccccc}
\hline Years & Branch & \multicolumn{2}{c}{ Trunk Shape } & \multicolumn{2}{c}{ Orchards } & Average \\
& Distance & Upright & Unshaped & B1 & B2 & \\
\hline \multirow{2}{*}{2012} & Near (NT) & 0.49 & 0.42 & 0.43 & 0.47 & 0.45 \\
& Medium & 0.51 & 0.41 & 0.43 & 0.49 & 0.46 \\
& (MT) & & & & & \\
& Far (FT) & 0.51 & 0.47 & 0.46 & 0.51 & 0.49 \\
& Average & $\mathbf{0 . 5 0}$ & $\mathbf{0 . 4 4}$ & $\mathbf{0 . 4 4}$ & $\mathbf{0 . 4 9}$ & 0.47 \\
& & & & & & \\
& & & & & & \\
& Near (NT) & 0.58 & 0.63 & 0.58 & 0.62 & 0.60 \\
& Medium & 0.63 & 0.64 & 0.61 & 0.65 & 0.63 \\
& (MT) & & & & & \\
& Far (FT) & 0.60 & 0.65 & 0.66 & 0.60 & 0.63 \\
& Average & $\mathbf{0 . 6 0}$ & $\mathbf{0 . 6 4}$ & $\mathbf{0 . 6 2}$ & $\mathbf{0 . 6 2}$ & 0.62 \\
& \multicolumn{2}{c}{ Insignificant } & & & \\
\hline
\end{tabular}

\section{CONCLUSION}

In this study, the effects of trunk shapes and shoot distance to trunk were determined, and the effects according to results were given in Table 13 . 
Trunk shapes were affected on fruit number, fruit diameter fruit length and fruit weight and shoot distance was mainly effected on fruit length and fruit flesh firmness. Although trunk shapes did not affect many parameters determined in present study, upright trunk shape and appropriate crown must be formed via pruning and training systems considering increase in fruit load in the following years. In addition, cultural practices and care conditions should be maintained. In conclusion further studies, particularly physiological studies should be performed in order to reveal effects of trunk shapes, branch distance to trunk and other factors on fruit quality and yield.

Table 13. Significance of evaluated parameters.

Çizelge 13. Incelenen parametrelerin önemlilik durumları.

\begin{tabular}{|c|c|c|c|c|c|c|}
\hline \multirow{3}{*}{ Parameters } & \multicolumn{6}{|c|}{ Years } \\
\hline & \multicolumn{3}{|c|}{2012} & \multicolumn{3}{|c|}{2013} \\
\hline & $\begin{array}{l}\text { Trunk } \\
\text { Shape }\end{array}$ & $\begin{array}{l}\text { Shoot } \\
\text { Distance }\end{array}$ & $\begin{array}{c}\text { Trunk Shape } \\
\times \text { Shoot } \\
\text { Distance } \\
\end{array}$ & $\begin{array}{l}\text { Trunk } \\
\text { Shape }\end{array}$ & $\begin{array}{c}\text { Shoot } \\
\text { Distance }\end{array}$ & $\begin{array}{c}\text { Trunk Shape } \\
\times \text { Shoot } \\
\text { Distance } \\
\end{array}$ \\
\hline Fruit number & - & - & - & * & - & - \\
\hline Harvested Fruit/Bud & - & - & - & - & - & - \\
\hline Fruit Diameter & - & - & - & ** & - & - \\
\hline Fruit Length & - & - & - & * & * & - \\
\hline Fruit Weight & - & - & - & $* *$ & - & - \\
\hline Yield & - & - & - & - & - & - \\
\hline Fruit Flesh Firmness & - & - & - & - & * & - \\
\hline $\begin{array}{l}\text { TSS in Harvest } \\
\text { Maturity }\end{array}$ & - & - & - & - & - & - \\
\hline TSS in Ripening & - & - & - & - & - & - \\
\hline TA in Harvest Maturity & - & - & - & - & - & - \\
\hline TA in Ripening & - & - & - & - & - & - \\
\hline \multicolumn{2}{|c|}{ **:Significant at $1 \%$ level } & \multicolumn{3}{|c|}{ *:Significant at $5 \%$ level } & \multicolumn{2}{|c|}{-:Insignificant } \\
\hline
\end{tabular}

\section{REFERENCES}

Aksu Uslu, N. (2006). A study on quantitative and qualitative effects of pruning and shoot growth on fruit quality and yield in kiwi fruit. Phd Thesis, University of Ondokuz Mayıs, Institute for Graduate Studies in Natural and Technology, Samsun, Turkey.

Basım, H., \& Uzun, H. İ. (2003). Fruit characteristics of kiwifruit in Antalya. National Kiwifruit and Grape Fruits Symposium, Ordu, Turkey,

Bostan, S.Z., \& Günay, K. (2014). The effects of altitude and direction on fruit quality of 'Hayward' (Actinidia deliciosa Planch) kiwifruit cultivar. Akademik Ziraat Dergisi, 3(1), 13-22.

Cangi, R., \& Karadeniz, T. (1999). The researches on yield and fruit characteristics in Hayward kiwifruit variety (Actinidia deliciosa) different elevations in Ordu. Black Sea Region Agriculture Symposium, University of Ondokuz Mayıs Faculty of Agriculture, Samsun, Turkey.

Cangi, R., \& Atalay, D. A. (2006). Effects of different bud loading levels on the yield, leaf and fruit characteristics of Hayward kiwifruit. Hort. Sci. (Prague), 33(1), 23-28.

Duman, G. (2011). Effects of different postharvest applications and packaging types on the storage and fruit quality of kiwi (Actinidia deliciosa). MSc Thesis, University of Çanakkale Onsekiz Mart, Institute for Graduate Studies in Natural and Technology, Çanakkale, Turkey.

Eriş, A. (1989). Türkiye İçin Yeni Bir Meyve Türü Kivi. Ziraat Bankası Yayınları, ISBN 975-7558-01-X, 50-60, Ankara.

Esen, Y. (2009). The determination of the most suitable growth and harvest time for the kiwifruit cultivation in Ünye. MSc Thesis, University of Ondokuz Mayıs, Institute for Graduate Studies in Natural and Technology, Samsun, Turkey.

Esen, Y., \& Özcan, M. (2016). The effect of different altitutes on fruit growth and harvest time in kiwifruit cultivation. Bahçe, 45(2), 509-514. 
Günay, K. (2009). Variation in important fruit quality characteristics in 'Hayward? (A. deliciosa Plach) kiwifruit of different elevations and directions in Ordu (Turkey) province. MSc Thesis, University of Ordu, Institute for Graduate Studies in Natural and Technology, Ordu, Turkey.

Kahraman, K. A. (2012). Growing problems and solutions of kiwifruit in Turkey. 1. International Workshop on kiwifruit. November 26-27, Atatürk Horticultural Central Research Institute, Yalova, Turkey.

Karaçalı, İ. (2006). Bahçe Ürünlerinin Muhafaza ve Pazarlanması. (Beşinci baskı). Ege Üniversitesi Basımevi, İzmir, Turkey.

Kadiroğlu Karaoğlan, H. (2011). Morphological changes from fruit set to harvesting time in Hayward kiwifruit variety. MSc Thesis, University of Namık Kemal, Institute for Graduate Studies in Natural and Technology, Tekirdağ, Turkey.

Kılıç, O., Çopur U. Ö., \& Görtay, Ş. (1991). Application guide for fruit and vegetable processing technology. Uludag University, Faculty of Agriculture, Lecture Notes.

Kubal, C. (2016). The important chemical and physical properties of kiwifruit 'Hayward' variety grown in Ordu province of Turkey. MSc Thesis, University of Ordu, Institute for Graduate Studies in Natural and Technology, Ordu, Turkey.

Özcan, M. (2016). Suptropic fruits lecture notes. Ondokuz Mayıs University, Faculty of Agriculture, Department of Horticulture, Samsun, Turkey.

Samancı, H. (1990). Kiwifruit (Actinidia) Growing. TAV publications (Tarımsal Araştırmaları Destekleme ve Geliştirme Vakfı), Publication number: 22, Yalova, Turkey.

Samancl, H., \& Uslu, I. (1998). Effect of cropping load, cane length and thinning on yield and fruit characteristics of kiwifruit (Actinidia deliciosa). IV. Viticulture Symposium, Yalova, Turkey.

Sarıçiçek, O. (2010). Effect of boron fertilization on yield and some leaf nutrient contents of kiwifruit. MSc Thesis, University of Ordu, Institute for Graduate Studies in Natural and Technology, Ordu, Turkey.

Şeker, M., Dardeniz, A., Kaynaş, K., \& Ulaş, Z. (2003a). The investigation of important plant characteristics of Hayward and Tomuri cultivars grown in Çanakkale district. National Kiwifruit and Grape Fruits Symposium, Ordu, Turkey

Şeker, M., Dardeniz, A., \& Kaynaş, K., (2003b). The effects of different pruning applications on phenological characteristics, fruit yield and quality of Hayward kiwifruit cultivar. National Kiwifruit and Grape Fruits Symposium, Ordu, Turkey.

Tarakçıoğlu, C., Aşkın, T., \& Samancı, R. (2006). Effects of organomineral fertilizer on yield and leaf nutrient contents of kiwifruit. 2nd National Grape Fruits Symposium, Tokat, Turkey.

Turkish State Meteorological Service. (2015). Samsun climate data. http://www.mgm.gov.tr. Access date: February $12,2016$.

TUiK. (2018). Kiwifruit production statistics. The Turkish Statistical Institute, http://www.tuik.gov.tr. Access date: January 11, 2019.

Yılmaz, B. (2016). The changing of important quality characteristics during fruit development on 'Hayward' kiwifruit cultivar grown in Giresun province (Turkey) conditions. MSc Thesis, University of Ordu Institute for Graduate Studies in Natural and Technology, Ordu, Turkey.

Zenginbal, H., Özcan, M., \& Haznedar, A. (2005). A study on phenologic observations and pomologic analysis in kiwifruit cultivars cultivated under Rize ecological conditions. Derim, 22(1), 1-9. 